\title{
Periphyton and Earthworms as Biological Indicators of Metal Pollution in Streams of Blantyre City, Malawi
}

\author{
C. C. Kaonga and M. Monjerezi \\ University of Malawi \\ Malawi
}

\section{Introduction}

Pollution of water and soils arises from overburdens of mines, application of fertilizers and pesticides, industrial effluents and sewage sludge (Alloway \& Ayres, 1997), among others. In heavily contaminated soils and water, there is a decrease in the population, growth and function of biota. In most cases all biological indices of environmental health (fish, invertebrates and algae) decline as pollution intensity increases (Cuffney et al., 2000; Hill et al., 2000; Khan, 1990). The identification of plant and animal species with the ability to accumulate metals is therefore of interest for the purposes of environmental monitoring (Chukwuma, 1998; Manly, 1996).

Earthworms and periphyton (attached algae) have been utilized as indicators of pollution of soils and water with metals (Ireland, 1983; Holan et al., 1993; McCormick \& Cairns, 1994; Ramelow, 1987; Jin-fen et al., 2000). Despite being very small, experiments unequivocally demonstrate that algae sequester heavy metals by complexation to phytochelatins (Gekeler et al., 1988), which is an identical mechanism as higher plants. In the context of biomonitoring, earthworms act as quantitative monitors of total-soil metal and also estimators of ecologically significant soil metal concentration (Morgan \& Morgan, 1988). Earthworms are important components of the soil system mainly because of their favourable effects on soil structure and function which include increasing soil fertility by formation of an organic matter layer in topsoil. The most widely studied earthworm species are Eisenia fetida, Eisenia Andrei, Lumbricus terrestris and Lumbricus rubellus (Georgescu \& Weber, 2007).

In Malawi, several studies have confirmed the presence of heavy metals in water and soils. Kadewa et al. (2001) found levels of copper, cadmium and chromium in soils fertilized by sewage sludge from Soche waste water treatment plant in Blantyre to be higher than the range for critical concentration for sludge amended soils. Sajidu et al. (2007) found that the levels of lead, cadmium, iron, manganese, zinc, chromium and nickel in streams in the city of Blantyre were much higher than World Health Organisation (WHO) safe limits for drinking water in all sampled streams after they had passed through industrial areas. Lakudzala et al. (1999) found that at some points on Mudi, Likhubula and Shire Rivers, the iron and lead levels exceeded WHO guideline limits. However, not much has been done on the use of biological indicators to assess the state of the environment. In addition, studies that assess levels of heavy metals in biota are lacking because they only target either 
invertebrates or aquatic plants only. Compounds of heavy metals in earthworms may be transferred to other species at higher trophic levels and may be lethal to earthworm consumers (Hui, 2002; Ireland and Richards, 1977; Ma, 1982; Vyas et al., 2000). Monitoring programs, with a well-founded scientific base and defined management outcomes, using biological indicators (such as algae, fungi, earthworms and other microorganisms), will expand our knowledge of river/aquatic function (Burns \& Ryder, 2001; Khosmanesh et al., 1996). This work reports on the levels of potentially harmful elements in the streams, wastewater and stream bank soils. In addition, aspects of metal accumulation in earthworms and green algae and their potential for biomontitoring are presented.

\section{Materials and methods}

\subsection{Study area}

Malawi is situated in South East Africa (Fig. 1a). This study was conducted in the City of Blantyre (Fig. 1b), the commercial and industrial city of Malawi. The City has eight designated industrial areas namely Makata, Ginnery corner, Maselema, Limbe, Chirimba, south Lunzu, Maone and Chitawira, with south Lunzu still under development (Fig. 1c). All the industrial sites are located along the banks of the main streams in the City. Makata industrial site lies between Mudi and Nasolo streams, Ginnery corner is along Mudi stream, Maselema is along Naperi River and Chirimba is along Chirimba stream (Fig. 1c). The sampling points fell into two major categories, which were; streams and wastewater treatment plants (WWTP). The waste water treatment plants were included because their effluent is released into the streams. Most of these streams pass through the major industrial areas except for Namangunda, which passes by a dumpsite and Michiru, which originates from a forest reserve and does not pass through the industrial sites (Fig. 1c).

\subsection{Sample collection}

All samples were collected in wet (November - February) and dry (July - October) seasons, to capture the effects of seasonal variation, from the selected streams and WWTPs in Blantyre City (Fig. 1). A total of eighteen periphyton (algae) samples were collected for each season. The samples were collected in $100 \mathrm{~mL}$ plastic bottles (Diatoms for Assessing River Ecological Status (DARES), 2004). The algae samples were chilled in a refrigerator pending analysis (New South Wales (NSW), 2002). The periphyton was identified as Spirogyra aequinoctialis.

Water samples were collected at an area where samples of $S$. aequinoctialis were collected. A total of forty three (43) water samples were collected for each season. Grab sampling method was used in the collection of water samples both upstream and downstream of a designated industrial area. At each sampling point, water samples were collected in triplicates for heavy metal analysis and a single sample for $\mathrm{pH}$ analysis. The samples were collected and stored in $1 \mathrm{~L}$ pre-cleaned new polyethylene bottles. Water samples for determination of metal were acidified to $\mathrm{pH}<2$ by adding concentrated nitric acid (Analytical Reagent (AR)) (American Public Health Association (APHA), 2005).

A total of forty-six (46) earthworm and soil samples were collected in both seasons. The earthworms were collected in $400 \mathrm{~mL}$ plastic bottles (at least three individuals per sampling site) into which a few holes were poked on the lid (Ecological Monitoring and Assessment Network (EMAN), 2004). Earthworm casts were used to find possible earthworm locations. Soil (stream sediment) samples were collected where earthworms were found using a soil 
auger. Soil samples were collected within the top soil range $(0-20 \mathrm{~cm})$ since most of the earthworms were found in this region. Soil horizons could not be distinguished in all these sampling points. Five augerings were collected at each site and were mixed in a bucket before sub sampling (quartering) (Anderson and Ingram, 1993). The samples were collected in plastic bags.
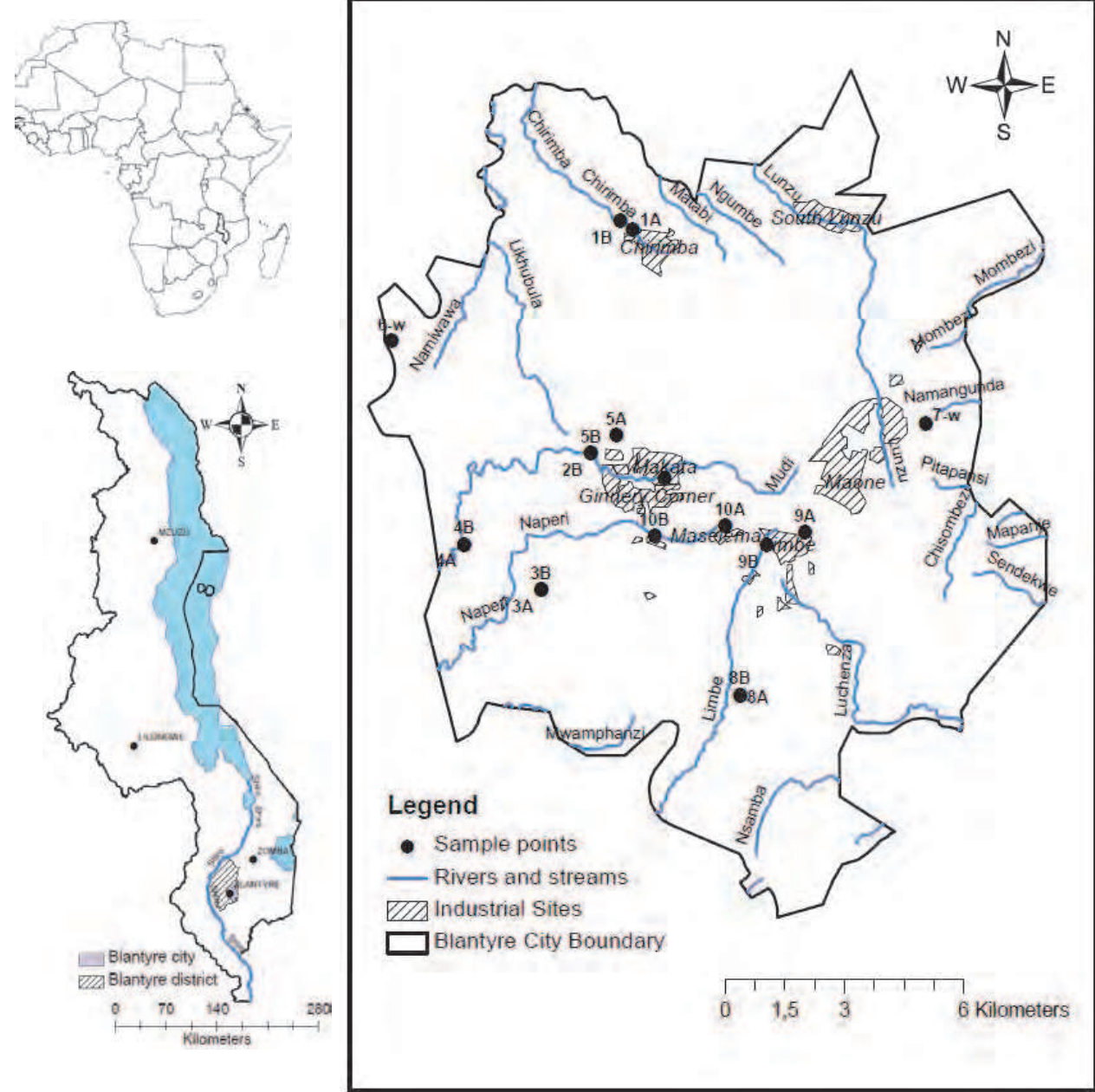

Fig. 1. Maps showing the location of Malaw1 in Atrica, Blantyre city in Malaw1 and sampling points in the City of Blantyre. Sample IDs are explained in Table 1.

\subsection{Analysis of water and wastewater samples}

$\mathrm{pH}$ was measured immediately after sampling using Orion Research digital ionalyzer 601A and Metrohm $744 \mathrm{pH}$ meters (ISO 10523-1:1994). Water samples were digested using concentrated nitric acid (AR). $50 \mathrm{~mL}$ of the sample was transferred to a beaker to which 5 
$\mathrm{mL}$ concentrated nitric acid was added and brought to a boil on a hot plate to the lowest volume possible (15 to $20 \mathrm{~mL}$ ). Filtration was done after digestion. The filtrate was then diluted to volume with distilled water in a $50 \mathrm{~mL}$ volumetric flask (APHA, 2005). Total concentrations of $\mathrm{Mn}, \mathrm{Cd}, \mathrm{Cr}, \mathrm{Cu}, \mathrm{Pb}, \mathrm{Ni}, \mathrm{Fe}, \mathrm{Zn}$ were determined using flame atomic absorption spectroscopy (Perkin Elmer, Analyst 700; APHA, 2005).

\subsection{Analysis of soil samples}

The soil samples were air dried, ground in a mortar and passed through a $2 \mathrm{~mm}$ sieve. $5.0 \mathrm{~g}$ of the dry sieved soil sample was heated with $10 \mathrm{~mL}$ concentrated nitric acid (AR) for 45 minutes. The soil samples were then dried, re-dissolved in $5 \mathrm{~mL}$ aqua regia ( $3: 1$ conc. $\mathrm{HCl}$ (AR) and conc. nitric acid (AR)) and filtered. Total concentrations of $\mathrm{Mn}, \mathrm{Cd}, \mathrm{Cr}, \mathrm{Cu}, \mathrm{Pb}, \mathrm{Ni}$, $\mathrm{Fe}, \mathrm{Zn}$ were determined using flame atomic absorption spectroscopy (Perkin Elmer, Analyst 700 and Buck Scientific AAS model 200A; Bamgbose et al., 2000). The total metal concentrations were expressed as $\mathrm{mg} / \mathrm{kg}$ dry weight of soil ( $\mathrm{mg} / \mathrm{kg} \mathrm{dw})$.

Soil organic matter was determined using the Walkley - Black method (Walkley and Black, 1934). Briefly, the soil samples were ground using a mortar and then passed through a $0.5 \mathrm{~mm}$ sieve. $1.00 \mathrm{~g}$ soil was mixed with $10 \mathrm{~mL}$ of $1 \mathrm{~N}$ potassium dichromate (AR) solution and $15 \mathrm{~mL}$ concentrated sulphuric acid (AR), whilst shaking. The mixture was then shaken for a further one minute and left to stand for thirty minutes. Then $150 \mathrm{~mL}$ distilled water and $5 \mathrm{~mL}$ concentrated phosphoric acid (AR) were added whilst shaking. After cooling, the mixture was titrated against $0.5 \mathrm{~N}$ ferrous ammonium sulphate (AR) solution, with $1 \mathrm{~mL}$ diphenylamine indicator. The colour change was from deep blue to dark green. Similarly triplicates of blank titrations were carried out. Where the volume of $0.5 \mathrm{~N}$ ferrous ammonium sulphate (AR) solutions was less than $3 \mathrm{~mL}$, the determinations were repeated using $0.5 \mathrm{~g}$ soil. The percentage organic matter was calculated using the following equation:

$$
\% \mathrm{OM}=1.729 \times 0.0031 \times 100 \times F \times\left[\frac{\mathrm{Me}_{\mathrm{K}_{2} \mathrm{Cr}_{2} \mathrm{O}_{7}}-\mathrm{Me}_{\mathrm{Fe}\left(\mathrm{NH}_{4}\right)_{2} \cdot 6 \mathrm{H}_{2} \mathrm{O}}}{\text { mass }(\mathrm{g}) \text { of air dried soil }}\right]
$$

where, $F=$ Correction factor $(1.33)$ and $\mathrm{Me}=$ Normality of solution $\times$ volume $(\mathrm{mL})$ of solution used.

Soil $\mathrm{pH}$ was determined using glass electrode $\mathrm{pH}$ meters (model 601A Orion Research digital ionalyzer and model $744 \mathrm{Metrohm})$ in a 1:5 (V/V) of soil in water $\left(\mathrm{pH}-\mathrm{H}_{2} \mathrm{O}\right)$.

\subsection{Analysis of metals in earthworm samples}

The earthworms were identified as Aporrectodea icteria after being rinsed with distilled water. Only reproductively mature earthworms were identified because of presence of a clitellum. Then they were placed on moist filter papers and put in glass Petri dishes (one individual per dish) and kept at $10^{\circ} \mathrm{C}$ for $24 \mathrm{hrs}$ in order to purge the soil in the gut. They were then rinsed slightly with distilled water and then stored frozen and then freeze-dried. Gut contents remaining in some earthworms were removed manually. 3.0g of thawed and dried earthworm sample was heated with $2 \mathrm{~mL}$ concentrated $\mathrm{HNO}_{3}$ (AR), filtered and made up to $50 \mathrm{~mL}$ with distilled water. The metal contents were determined by running samples on AAS as for the soil samples. The metal concentrations were expressed as $\mathrm{mg} / \mathrm{kg}$ dry weight of earthworm $(\mathrm{mg} / \mathrm{kg} \mathrm{dw})$. 


\subsection{Analysis of metals in S. aequinoctialis samples}

Periphyton samples were air dried (Hoffman, 1996). The air dried samples were then dryashed in a furnace after adding nitric (AR) and hydrochloric acid (AR) (Association of Official Analytical Chemists (AOAC), 1990). Thereafter the sample was made up to $50 \mathrm{~mL}$ with distilled water in a volumetric flask. The samples were prepared in triplicates and blank and standard samples were used to check accuracy of analysis. The concentration of heavy metals was determined by running samples on AAS (Perkin Elmer, Analyst 700).

\subsection{Quality control}

To ensure quality control of sampling and analysis, a number of procedures were followed. Firstly the sampling devices were carefully chosen so that they should not contaminate the samples. If the same apparatus were to be used for the next sampling process, they were thoroughly cleaned and rinsed with distilled water. For water samples in which heavy metals were to be determined, acidification was done to $\mathrm{pH}$ less than 2 to avoid adsorption of metals on the sides of the sampling containers. In the measurement of volume a pipette which is more accurate was used rather than measuring cylinders. Soil samples were prepared away from the rest of the samples since dust could easily contaminate the other samples. All samples for heavy metal analysis were determined in triplicates. Analytical reagents were used for all procedures rather than general purpose reagents. In addition, the following minimum laboratory quality control measures (United States Environmental Protection Agency (US-EPA), 2010) for the instruments used in the analysis and also samples were followed;

a. Initial calibration; This was done prior to analysis of samples (minimum three concentration levels for every compound and an instrument blank).

b. Continuing calibration; This was done once per 10 samples (mid-level standard containing all compounds) and a continuing calibration blank.

c. Method blank; This was done once per digestion or extraction set.

d. Soil and water samples were preserved at $4{ }^{\circ} \mathrm{C}$ and analysed within 28 days.

\section{Results}

\subsection{Metal concentrations in stream water, wastewater and S. aequinoctialis}

Table 1 provides the levels of determined metals in stream water and wastewater samples. The corresponding World Health Organization (WHO) drinking water guidelines (WHO, 2006) and the Malawi Standard (MS 214) (MBS, 2005) for the parameters are also included in Table 1. The levels of metals determined in S. aequinoctialis samples are provided in Table 2. In $S$. aequinoctialis samples, concentrations of manganese, cadmium and copper were significantly higher $(p<0.05)$ in the dry season than in the rainy season. There were, however, no significant seasonal differences in the levels of lead, zinc, chromium and nickel.

Chromium and copper were not detected in all samples in the rainy season, but they were measured in levels of up to $0.419 \mathrm{mg} / \mathrm{L}$ and $0.076 \mathrm{mg} / \mathrm{L}$, respectively, in the dry season (Table 1). For both seasons, the determined levels of zinc and copper were below MS 214 and WHO water quality guidelines, whereas levels of nickel and cadmium were above these guidelines (Table 1). 17\% of the samples had chromium levels above the MS 214 (0.05-0.1 $\mathrm{mg} / \mathrm{L})$ and WHO (0.05 mg/L) water quality standards. For lead, $44 \%$ and $61 \%$ of the 
sampled points contained lead levels above MS $214(0.01-0.05 \mathrm{mg} / \mathrm{L})$ and WHO (0.01 $\mathrm{mg} / \mathrm{L}$ ) drinking water standards in the rainy and dry seasons, respectively. In the case of manganese, water quality standards were only exceeded at Mangunda stream, in the rainy season. In the dry season, however, $83 \%$ and $17 \%$ of the sampling points showed manganese levels above the MS 214 and WHO drinking water quality guidelines, respectively (Table 1).

\subsection{Metal content in soils and $\boldsymbol{A}$. icteria}

Table 3 and Table 4 provide results of soil and earthworm sample analyses, respectively. The metal content in the assessed soil sites is low in comparison to guideline values in several European countries. Levels of $\mathrm{Cd}$ (rainy season), $\mathrm{Pb}, \mathrm{Cr}, \mathrm{Cu}, \mathrm{Zn}$ and $\mathrm{Ni}$ (both seasons) were below their respective England toxic limits $(0.06 \mathrm{mg} / \mathrm{kg}$ for Cd, $10 \mathrm{mg} / \mathrm{kg}$ for $\mathrm{Pb}, 50 \mathrm{mg} / \mathrm{kg}$ for $\mathrm{Zn}, 20 \mathrm{mg} / \mathrm{kg}$ for $\mathrm{Cr}$ and $40 \mathrm{mg} / \mathrm{kg}$ for Ni; Bohn et al, 1985), Swiss guide levels $(0.8 \mathrm{mg} / \mathrm{kg}$ dry soil for $\mathrm{Cd}, 50 \mathrm{mg} / \mathrm{kg}$ dry soil for $\mathrm{Pb}$; OIS, 1998) and the Netherlands target levels $(85 \mathrm{mg} / \mathrm{kg}$ for $\mathrm{Pb}, 36 \mathrm{mg} / \mathrm{kg}$ for $\mathrm{Cu}, 140 \mathrm{mg} / \mathrm{kg}$ for $\mathrm{Zn}$, $100 \mathrm{mg} / \mathrm{kg}$ for $\mathrm{Cr}, 35 \mathrm{mg} / \mathrm{kg}$ for Ni; Alloway and Ayres, 1997 ). However, for the dry season, $33 \%$ of the soil samples were above the England toxic level $(0.06 \mathrm{mg} / \mathrm{kg}$; Bohn et al., 1985).

The internal concentrations of $\mathrm{Cd}, \mathrm{Cu}, \mathrm{Pb}, \mathrm{Zn}$ and $\mathrm{Cr}$ were below the levels that show significant changes in (sub-) lethal endpoints for earthworms (see e.g. Langdon et al, 2001; Spurgeon and Hopkin, 1999; Spurgeon et al, 2000). There were significantly higher concentrations of $\mathrm{Cd}$ in A. icteria than in the soils, but significantly lower values of $\mathrm{Mn}, \mathrm{Fe}$, $\mathrm{Pb}, \mathrm{Cr}, \mathrm{Zn}$ and $\mathrm{Cu}$ in the earthworm than soils $(p<0.05)$. There was no significant difference in the concentrations of $\mathrm{Ni}$ in soils and earthworms $(p>0.05)$. The effect of seasonality varies among the studied metals. In the soils, levels of Mn were significantly higher in dry season than the rainy season $(p<0.05)$, but there were no significant differences between the seasons for the values of total soil concentrations of $\mathrm{Cd}, \mathrm{Cu}, \mathrm{Zn}, \mathrm{Pb}, \mathrm{Cr}$ and $\mathrm{Ni}(p>0.05)$. $\mathrm{pH}$ was significantly higher in the rainy season than the dry season $(p<0.05)$, but there were no significant differences in soil OM content between the seasons $(p>0.05)$. In A. icteria, levels of $\mathrm{Cd}$ and $\mathrm{Cr}$ were significantly higher in dry season than the rainy season $(p<0.05)$, but there were no significant differences between the seasons for the values of concentrations of $\mathrm{Mn}, \mathrm{Cu}, \mathrm{Zn}, \mathrm{Pb}, \mathrm{Ni}$ and $\mathrm{Ca}(p>0.05)$.

\section{Discussion}

\subsection{Potential sources of metal pollution}

Pearson correlations were calculated to find empirical inter-relationships between the chemical parameters. Correlation between chemical parameters may indicate similar origins or conceptual relationships, as well as common governing factors. In the soil samples, concentrations of $\mathrm{Cr}$ were significantly correlated with $\mathrm{Zn}, \mathrm{Cu}$ and $\mathrm{Pb}$ in the rainy season and with $\mathrm{Pb}$ in the dry season (Table 5). The strong association of these metals with each other indicates their anthropogenic origin. Organic matter content strongly affects the soil content of $\mathrm{Cd}, \mathrm{Zn}$ (rainy season) and $\mathrm{Cr}$ (Table 5).

The presence of heavy metal pollution in the streams of Blanytre City has been reported upon by Sajidu et al (2007) and Kuyeli (2007) and both studies pointed at industrial activities as the possible sources of pollution. Kuyeli (2007) reported $\mathrm{Cd}$ in effluent from printing $(0.034 \mathrm{mg} / \mathrm{l})$, textiles $(0.034 \mathrm{mg} / \mathrm{l})$, motor oil $(0.025 \mathrm{mg} / \mathrm{l})$, battery $(0.019 \mathrm{mg} / \mathrm{l})$ and abattoir 
industry $(0.06 \mathrm{mg} / \mathrm{l})$ in the dry season; $\mathrm{Cr}$ in effluent from match stick production $(41.59$ $\mathrm{mg} / \mathrm{l}$ in the dry season and $56.12 \mathrm{mg} / 1$ in the rainy season); $\mathrm{Cu}$ in the range $0.026 \mathrm{mg} / \mathrm{l}$ (battery manufacturer) to $2.00 \mathrm{mg} / \mathrm{l}$ (Paint industry); $\mathrm{Zn}$ in effluent from battery manufacturer $(30.83 \mathrm{mg} / \mathrm{l})$ and match stick production $(15.51 \mathrm{mg} / \mathrm{l})$ in the rainy season and $18.97 \mathrm{mg} / 1$ (match stick), $13.9 \mathrm{mg} / 1$ (battery) and $14.4 \mathrm{mg} / 1$ (fertiliser manufacturer) in the dry season; $\mathrm{Pb}$ in paint $(1.29 \mathrm{mg} / \mathrm{l})$, printing $(2.60 \mathrm{mg} / \mathrm{l})$ in the dry season and match stick $(0.465 \mathrm{mg} / \mathrm{l})$ and printing $(0.233 \mathrm{mg} / \mathrm{l})$ in the rainy season. Sajidu et al (2007) reported a significant increase in the levels of $\mathrm{Pb}, \mathrm{Cd}, \mathrm{Cr}, \mathrm{Fe}, \mathrm{Cu}, \mathrm{Ni}$ and $\mathrm{Mn}$ in the same Blantyre streams after passing through an industrial site. The results from this study show enrichment of the heavy metals $(\mathrm{Zn}, \mathrm{Cd}, \mathrm{Cr}$ and $\mathrm{Pb}$ ) in most streams over that of Michiru stream, which is in a forest reserve. In Malawi, cadmium is present in coatings on steel and also in batteries and potassium dichromate $\left(\mathrm{K}_{2} \mathrm{Cr}_{2} \mathrm{O}_{7}\right)$ is used as a raw material for producing match-heads. Copper compounds are used in textile, print and paint industry for pigmentation whereas $\mathrm{Pb}$ is used as a pigment, dispersing and drying agent in the print and paint industry. In match stick production lead oxide is used to give the scarlet colour of the match.

\subsection{Accumulation of metals in S. aequinoctialis}

Calculated bioconcentration factors (BCF) show that $S$. aequinoctialis accumulated heavy metals in the order $\mathrm{Mn}>\mathrm{Zn}>\mathrm{Cu}>\mathrm{Pb}$ (Table 6). S. aequinoctialis had significantly higher $(p<$ $0.05)$ levels of lead, copper, zinc and manganese than the corresponding water samples, in both seasons. There were no significant differences in levels of chromium between the algae samples and water samples whereas the differences were season dependent for the other metals. Water samples had high cadmium levels in the rainy season while in the dry season the levels were higher in S. aequinoctialis. For nickel, water samples indicated significantly higher nickel levels than $S$. aequinoctialis $(p<0.05)$, in the rainy season, but there was no significant difference in the dry season $(p>0.05)$.

There were strong correlations between water and algae metal contents for $\mathrm{Cu}(r=0.73 ; p<$ 0.05; Fig. 2a) and $\mathrm{Cr}(r=0.65 ; p<0.05)$ in the rainy season. A low correlation for $\mathrm{Mn}(r=$ $0.40 ; p<0.05)$ was also obtained for the dry season. There were no correlations for the other metals. There is an established consensus in the literature that brown and green algae are capable of biosorption of metals from their environment (Davis et al., 2003; Rajfur et al., 2010). They have thus been used in biomonitoring of heavy metals mostly in marine environments (Filho et al., 1999; Żbikowski et al., 2007; Akcali and Kucuksezgin, 2011). This study is in agreement with these studies and adds to the knowledge of heavy metal accumulation of green algae in a fresh water environment. Heavy metal levels in algae species are dependent both on environmental parameters (salinity, temperature, $\mathrm{pH}$, light, oxygen, nutrient concentrations, complexing agents) and on the structural differences among the algae species (Garnharm et al., 1992; Favero et al., 1996).

\subsection{Metal accumulation in A.icteria}

Concentrations of $\mathrm{Cu}, \mathrm{Zn}$ (rainy season) and $\mathrm{Cd}$ (dry season) in the soil were significantly correlated with the concentrations in A.icteria (Fig. 2b-d); Table 5). These metals also show correlations of varying strength with soil OM content (Table 5). The calculated bioconcentration factors (BCF) show that A. icteria accumulated heavy metals in the order $\mathrm{Cd}>\mathrm{Zn}=\mathrm{Ni}>\mathrm{Pb}>\mathrm{Cu}=\mathrm{Cr}$ (Table 7), consistent with data from other similar studies (e.g. 


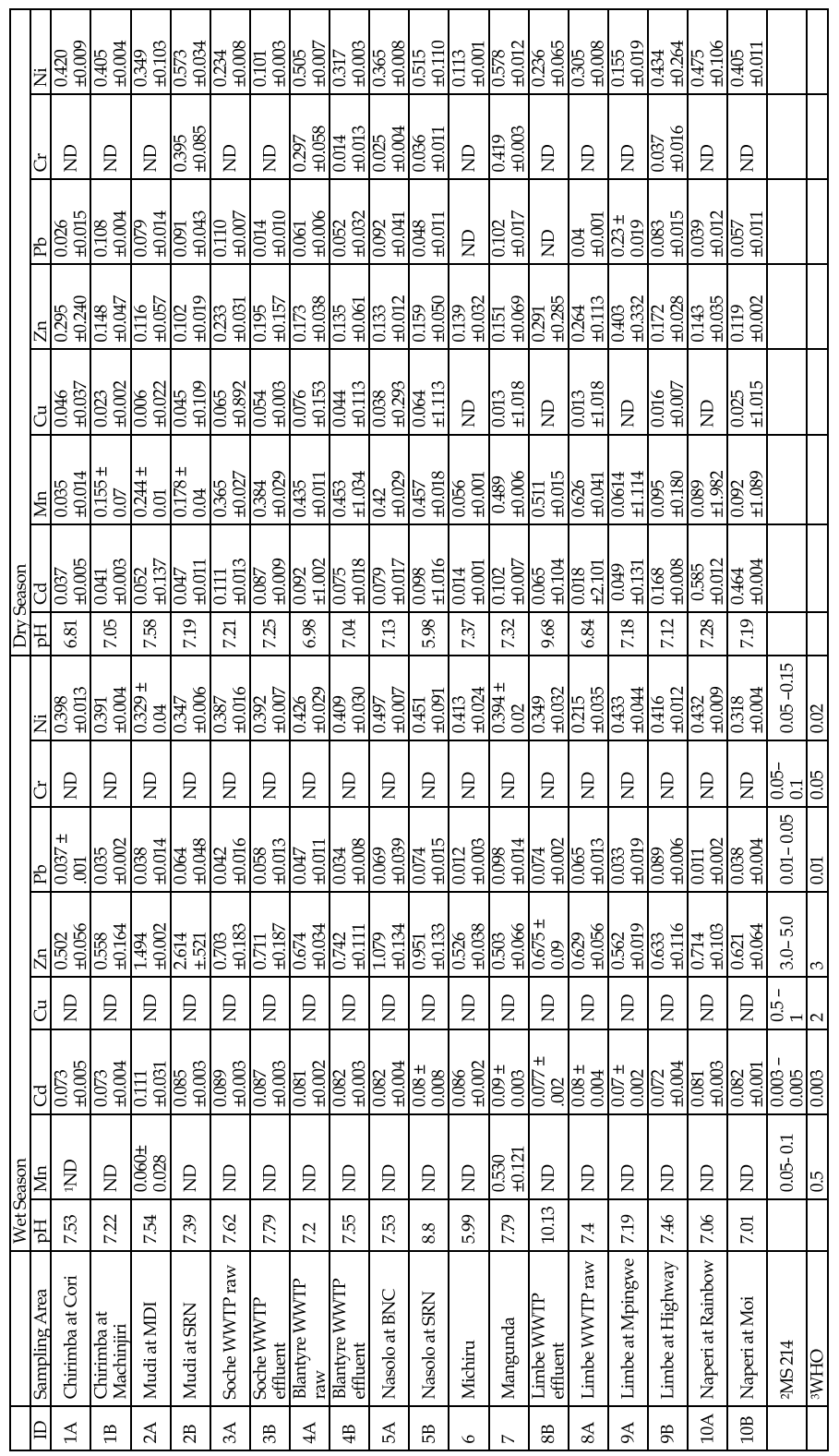

${ }^{1}$ Not detected

${ }^{2}$ Malawi Bureau of standards (Standards for drinking water)

${ }^{3}$ World Health Organisation (Standards for drinking water)

Values are in the form of mean \pm standard deviation

Table 1. Levels of $\mathrm{Ni}, \mathrm{Cu}, \mathrm{Fe}, \mathrm{Pb}, \mathrm{Cr}, \mathrm{Cd}, \mathrm{Mn}$ and $\mathrm{Zn}$ in water samples (concentrations are in $\mathrm{mg} / \mathrm{L}$ ) 


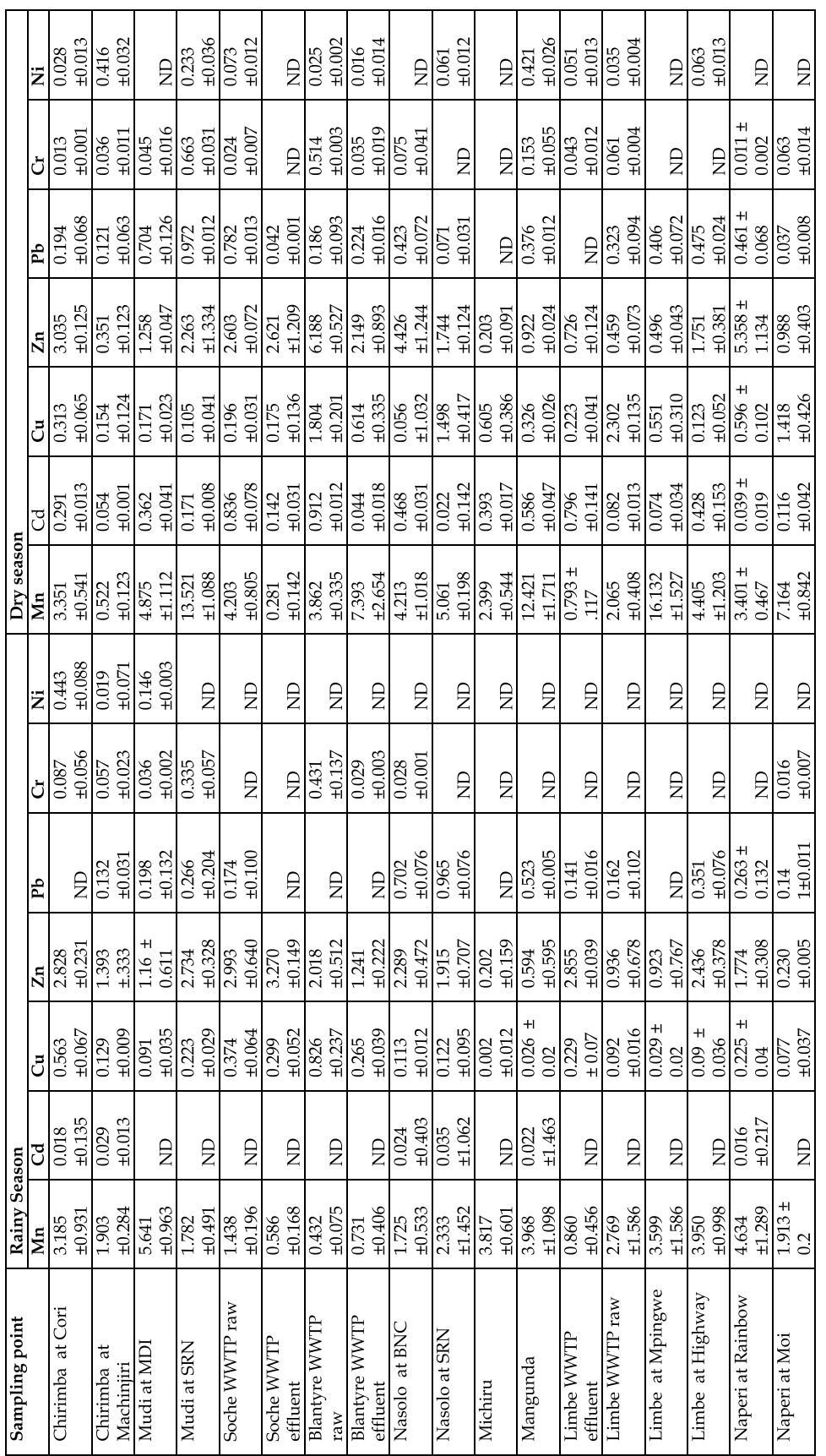

ND - not detected (below detection limit)

Table 2. Levels of heavy metals in S. aequinoctialis (in $\mathrm{mg} / \mathrm{kg}$ dry weight) 


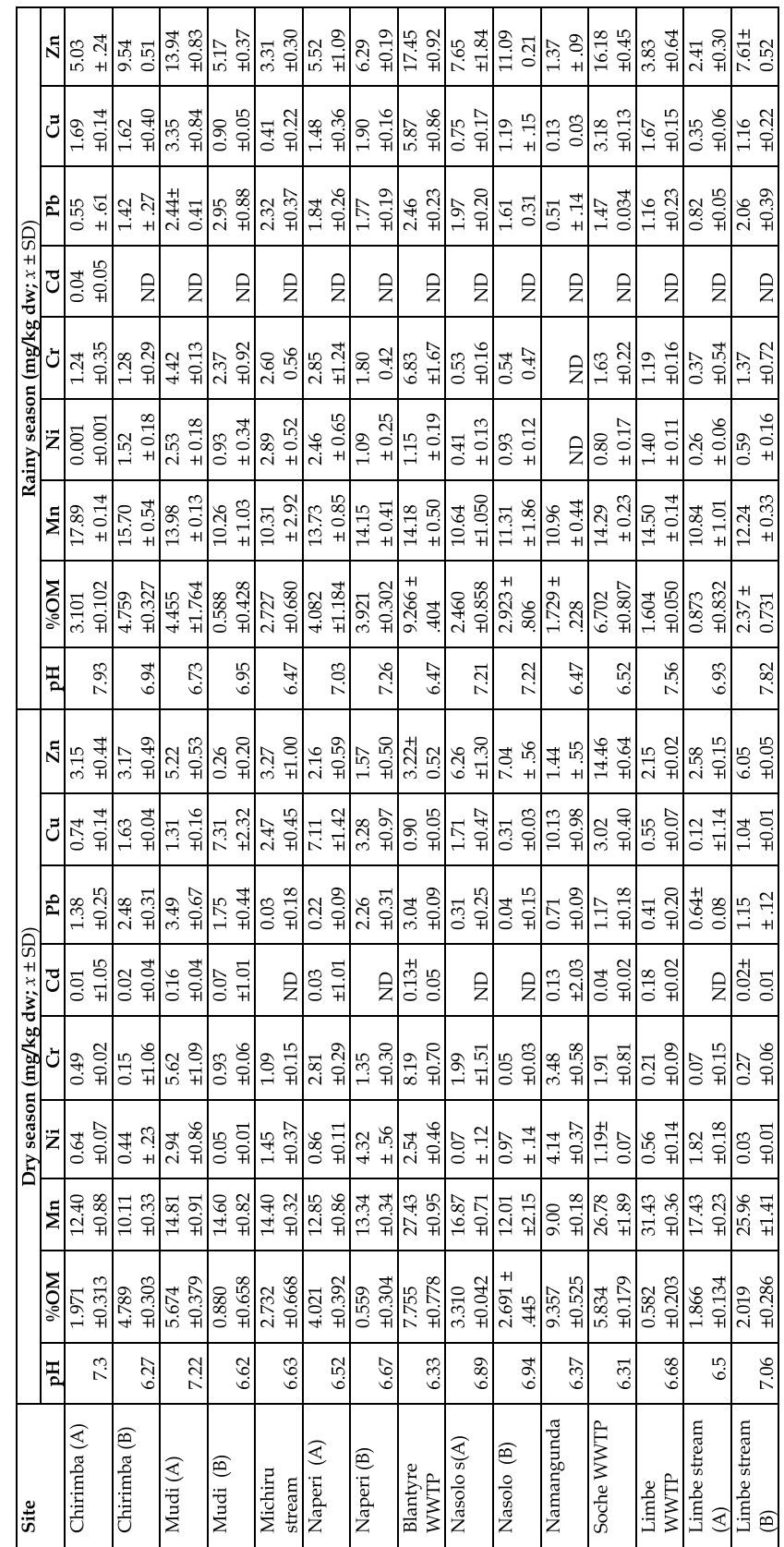

$x=$ mean value $(n=3) ; \mathrm{SD}=$ standard deviation; $\mathrm{ND}=$ not detected (below detection limit)

Table 3. Metal concentrations in stream sediments soils and soils around WWTPs in the study area 


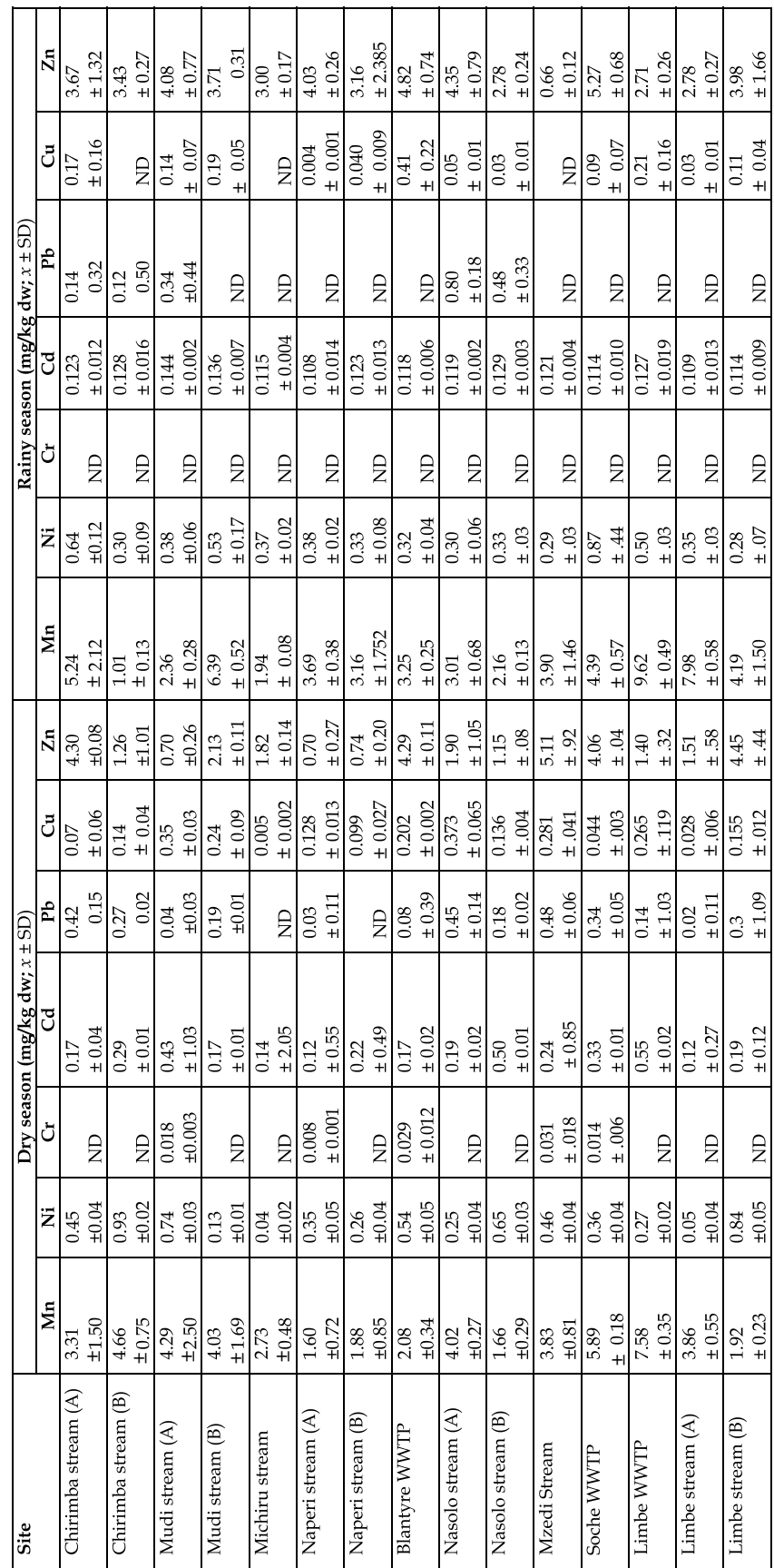

Table 4. Metal concentrations in A. icteria inhabiting stream- sediments and soils around WWTPs in Blantyre City, Malawi 


\begin{tabular}{|c|c|c|c|c|c|c|c|c|c|c|c|c|c|c|c|c|}
\hline & $\% \mathrm{OM}$ & $\mathrm{pH}$ & {$[\mathrm{Cd}]_{\mathrm{s}}$} & $\overline{\mathrm{Cd}]_{\mathrm{w}}}$ & {$[\mathrm{Pb}]_{\mathrm{s}}$} & $\overline{\mathrm{Pb}]_{\mathrm{w}}}$ & $\overline{M n}]_{\mathrm{s}}$ & $\overline{M n}]_{\mathrm{w}}$ & {$[\mathrm{Cu}]_{\mathrm{s}}$} & {$[\mathrm{Cu}]_{\mathrm{w}}$} & {$[\mathrm{Zn}]$} & {$[\mathrm{Zn}]_{\mathrm{w}}$} & {$[\mathrm{Cr}]_{\mathrm{s}}$} & {$[\mathrm{Cr}]_{\mathrm{w}}$} & {$[\mathrm{Ni}]_{\mathrm{s}}$} & {$[\mathrm{Ni}]_{\mathrm{w}}$} \\
\hline$\overline{\mathrm{OM}}$ & 1 & -0.39 & ND & -0.09 & 0.23 & -0.68 & 0.49 & -0.46 & $0.89^{* \star *}$ & 0.49 & $0.84^{\star \star}$ & $0.61^{*}$ & $0.69^{* \star}$ & ND & 0.17 & 0.17 \\
\hline$\overline{\mathrm{pH}}$ & -0.40 & 1 & ND & 0.03 & -0.25 & 016 & 036 & & -025 & -0.21 & & 0.02 & $-0.53^{*}$ & $\overline{\mathrm{II}}$ & -0.51 & 016 \\
\hline$[\mathrm{Cd}]_{\mathrm{s}}$ & 0.25 & $\mid-0.02$ & 1 & ND & ND & $\mathrm{ND}$ & $\overline{\mathrm{ND}}$ & ND & $\overline{\mathrm{ND}}$ & $\overline{\mathrm{ND}}$ & $\overline{\mathrm{NL}}$ & $\mathrm{ND}$ & ND & $\mathrm{ND}$ & ND & $\overline{\mathrm{NL}}$ \\
\hline$[\mathrm{Cd}]_{\mathrm{w}}$ & -0.03 & \begin{tabular}{|l|l|}
0.18 \\
\end{tabular} & $0.63^{*}$ & 1 & 0.29 & -0.29 & 0.12 & -0.1 & 0.1 & 0.25 & 0.2 & -0.08 & 0.16 & ND & 0.16 & 004 \\
\hline$[\mathrm{Pb}]_{\mathrm{s}}$ & 0.28 & 0.02 & 0.20 & 0.04 & 1 & \begin{tabular}{|l|l|}
0.54 \\
\end{tabular} & -0.32 & -0.31 & 0.33 & 0.31 & 0.41 & $0.53^{x}$ & $0.59^{*}$ & ND & 0.46 & 0.15 \\
\hline$[\mathrm{Pb}]_{\mathrm{w}}$ & 0.18 & \begin{tabular}{|l}
0.10 \\
\end{tabular} & -0.31 & -0.097 & -0.23 & 1 & $-0.91^{*}$ & -0.045 & 0.45 & -0.82 & 0.07 & 0.35 & -0.28 & ND & -0.19 & -0.50 \\
\hline$[\mathrm{Mn}]_{\mathrm{s}}$ & -0.08 & -0.09 & 0.31 & 0.25 & 0.03 & -0.20 & 1 & -0.012 & 0.50 & $\begin{array}{ll}0.31 \\
\end{array}$ & 0.31 & 0.31 & 0.16 & ND & -0.08 & 0.38 \\
\hline $\mathrm{Mn}]_{\mathrm{w}}$ & -0.02 & $\mid-0.17$ & 0.39 & 0.50 & 0.000 & 0.13 & 0.39 & 1 & -0.17 & 0.15 & -0.41 & -0.16 & -0.26 & ND & 0.39 & 0.35 \\
\hline$[\mathrm{Cu}]_{\mathrm{s}}$ & 0.35 & -0.38 & -0.02 & -0.30 & -0.13 & 0.23 & -0.41 & -0.09 & 1 & $0.73^{* *}$ & $0.85^{* \star}$ & $0.63^{*}$ & $0.81^{\star *}$ & ND & 0.09 & 0.21 \\
\hline$[\mathrm{Cu}]_{\mathrm{w}}$ & 0.26 & 0.22 & $0.83^{\star \star}$ & 0.33 & 0.24 & 0.12 & 0.05 & 0.26 & 0.18 & 1 & 0.42 & 0.31 & $0.72^{\star \star}$ & ND & 0.007 & 0.092 \\
\hline$[\mathrm{Zn}]_{\mathrm{s}}$ & 0.21 & \begin{tabular}{|l|l|}
0.03 \\
\end{tabular} & -0.23 & 0.29 & -0.08 & 0.25 & 0.36 & 0.1 & -0.23 & -0.15 & 1 & $0.72^{\star *}$ & $0.56^{*}$ & ND & 0.04 & 0.23 \\
\hline $\mathrm{Zn}]_{\mathrm{w}}$ & 0.47 & -0.07 & -0.15 & -0.25 & 0.026 & $0.61^{*}$ & 0.27 & -0.007 & -0.31 & -0.04 & 0.22 & 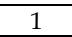 & 0.48 & $\mathrm{ND}$ & -0.08 & 0.41 \\
\hline$[\mathrm{Cr}]_{\mathrm{s}}$ & $71^{* *}$ & -0.15 & 0.53 & -0.09 & $0.56^{*}$ & -0.24 & \begin{tabular}{|l|l|}
0.154 \\
\end{tabular} & $\begin{array}{l}-0.17 \\
\end{array}$ & $\begin{array}{l}0.18 \\
\end{array}$ & 0.41 & -0.007 & 0.22 & 1 & $\mathrm{ND}$ & 0.46 & -0.09 \\
\hline$[\mathrm{Cr}]_{\mathrm{w}}$ & $0.96^{* *}$ & \begin{tabular}{|l|} 
\\
\end{tabular} & 0.73 & 0.011 & 0.33 & \begin{tabular}{|l|l|}
0.44 \\
\end{tabular} & 0.004 & -0.03 & 0.15 & 0.50 & -0.38 & 0.73 & 0.56 & 1 & ND & ND \\
\hline$[\mathrm{Ni}]_{s}$ & 0.44 & -0.20 & 0.60 & -0.003 & 0.36 & -0.08 & -0.236 & -0.19 & 0.09 & 0.04 & -0.21 & 0.05 & 0.49 & 0.86 & 1 & $\begin{array}{l}-0.21 \\
\end{array}$ \\
\hline i $w_{w}$ & 0.36 & 0.20 & -0.20 & 0.34 & 0.46 & 0.099 & -0.04 & -0.13 & 0.28 & 0.24 & 0.22 & 0.16 & 0.17 & 0.33 & -0.06 & 1 \\
\hline
\end{tabular}

** Correlation is significant at the 0.01 level; ${ }^{*}$ Correlation is significant at the 0.05 level; $\mathrm{ND}=$ not determined

Table 5. Pearson's correlation coefficients of soil OM, $\mathrm{pH}-\mathrm{H}_{2} \mathrm{O}$, metal soil and A.icteria metal content (Upper panel - rainy season Lower panel - dry season)
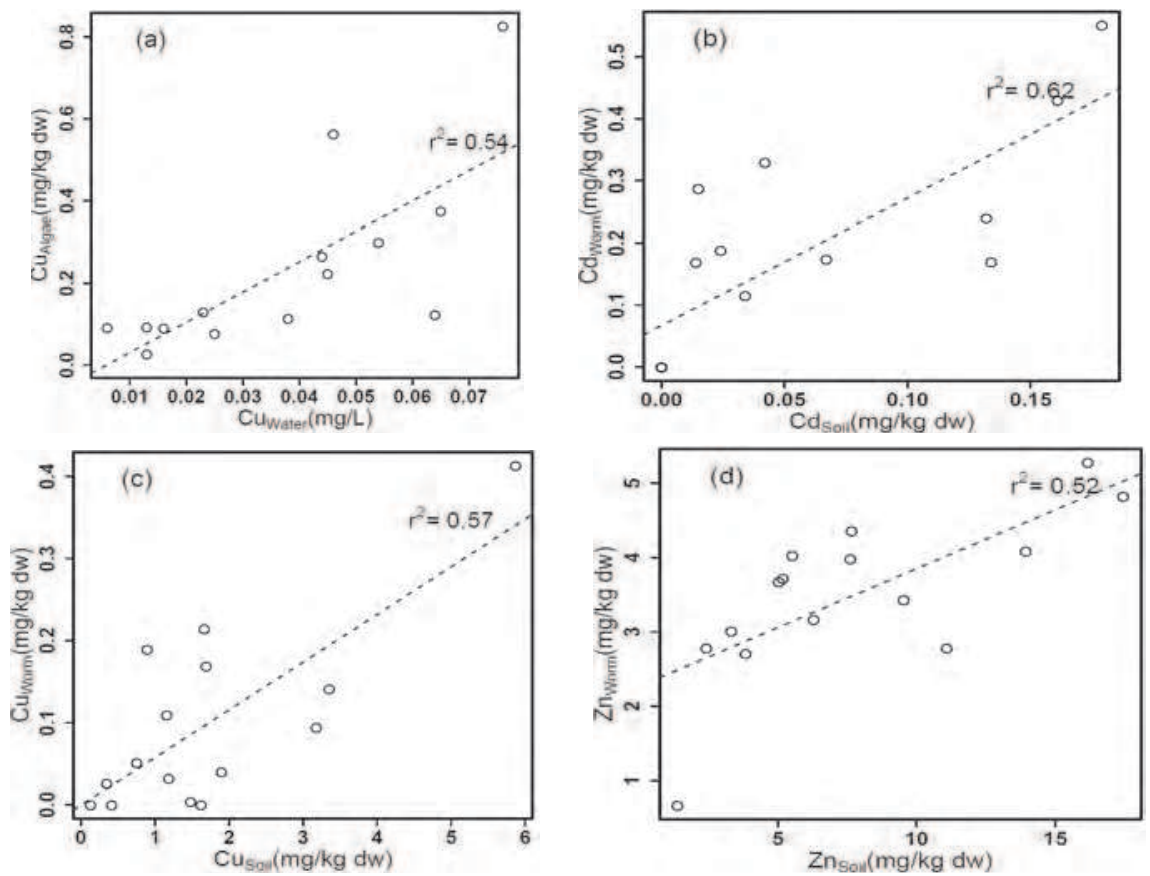

Fig. 2. Scatter plots showing relationship between metal content in A.icteria and sediments $(b-d)$ and metal content in $S$. aequinoctialis and stream water $(a)$. Dry season data is used for plot (b) and rainy season data is used for the other plots. No significant correlations were found for the other combinations of metals. 


\begin{tabular}{|c|c|c|c|c|c|c|c|c|c|c|c|c|c|c|}
\hline \multirow[t]{2}{*}{ Site } & \multicolumn{7}{|c|}{ Dry season } & \multicolumn{7}{|c|}{ Rainy season } \\
\hline & Mn & $\mathrm{Ni}$ & $\mathrm{Cr}$ & $\mathrm{Cd}$ & $\mathrm{Pb}$ & $\mathrm{Cu}$ & Zn & Mn & $\mathrm{Ni}$ & $\mathrm{Cr}$ & $\mathrm{Cd}$ & $\mathrm{Pb}$ & $\mathrm{Cu}$ & $\mathrm{Zn}$ \\
\hline $\mathrm{Cl}$ & ND & 0.07 & ND & 3.99 & 5.24 & ND & 6.05 & 91.00 & 1.05 & ND & 0.49 & 0.00 & 12.24 & 9.59 \\
\hline Chiri & ND & 1.06 & ND & 0.74 & 3.46 & ND & 0.63 & 12.28 & 0.05 & ND & 0.71 & 1.22 & 5.61 & 9.41 \\
\hline Mudi at MDI & 81.25 & ND & ND & 3.26 & 18.53 & ND & 0.84 & 23.12 & 0.42 & ND & 0.00 & 2.51 & 15.17 & 10.00 \\
\hline Mudi at SRN & ND & 0.67 & ND & 2.01 & 15.19 & ND & 0.87 & 10.01 & ND & 0.85 & 0.00 & 2.92 & 4.96 & 26.80 \\
\hline Sock & ND & 0.19 & ND & 9.39 & 18.62 & ND & 3.70 & 3.94 & ND & ND & 0.00 & 1.58 & 5.75 & 12.85 \\
\hline Soche WWTP efflu & ND & ND & ND & 1.63 & 0.72 & $\mathrm{ND}$ & 3.69 & 1.53 & ND & ND & 0.00 & 0.00 & 5.54 & 16.77 \\
\hline Blantyre & ND & 0.06 & ND & 11.26 & 3.96 & $\mathrm{ND}$ & 9.18 & 0.99 & ND & 1.45 & 0.00 & 0.00 & 10.87 & 11.66 \\
\hline Blanty & ND & 0.04 & ND & 0.54 & 6.59 & ND & 2.90 & 1.61 & ND & 2.07 & 0.00 & 0.00 & 6.02 & 9.19 \\
\hline Nasolo at BNC & ND & 0.00 & ND & 5.71 & 6.13 & ND & 4.10 & 4.11 & ND & 1.12 & 0.30 & 7.63 & 2.97 & 17.21 \\
\hline Naso & ND & 0.14 & ND & 0.28 & 0.96 & ND & 1.83 & 5.11 & ND & ND & 0.36 & 20.10 & 1.91 & 12.04 \\
\hline Michiru & ND & ND & ND & 4.57 & 0.00 & $\mathrm{ND}$ & 0.39 & 68.16 & ND & ND & 0.00 & ND & ND & 1.45 \\
\hline Mangunc & 23.44 & 1.07 & $\mathrm{ND}$ & 6.51 & 3.84 & ND & 1.83 & 8.11 & ND & ND & 0.22 & 5.13 & 2.00 & 3.93 \\
\hline Limbe WWTP efflu & ND & 0.15 & ND & 10.34 & 0.00 & ND & 1.08 & 1.68 & ND & ND & 0.00 & ND & ND & 9.81 \\
\hline Limbe WWTP raw & ND & 0.16 & ND & 1.03 & 4.97 & ND & 0.73 & 4.42 & ND & ND & 0.00 & 4.05 & 7.08 & 3.55 \\
\hline Limbe at Mpingwe & ND & 0.00 & ND & 1.06 & 12.30 & ND & 0.88 & 73.45 & ND & ND & 0.00 & 0.00 & ND & 2.29 \\
\hline Limbe at Highway & ND & 0.15 & ND & 5.94 & 5.34 & ND & 2.77 & 23.51 & ND & ND & 0.00 & 4.23 & 5.63 & 14.16 \\
\hline Naperi at Rainbc & ND & 0.00 & ND & 0.48 & 41.91 & ND & 7.50 & 7.92 & ND & ND & 0.18 & 6.74 & ND & 12.41 \\
\hline Naperi at Moi & ND & 0.00 & ND & 1.41 & 0.97 & ND & 1.59 & 4.12 & ND & ND & 0.00 & 0.00 & 3.08 & 1.93 \\
\hline
\end{tabular}

$\mathrm{ND}=$ not determined (because metal content was below detection limit in either water or algae)

Table 6. Bioconcentration factors (BCF) for rainy and dry seasons for S. aequinoctialis from the sampled streams in Blantyre City, Malawi.

\begin{tabular}{|l|l|l|c|l|l|l|l|l|l|l|l|l|l|l|}
\hline \multirow{2}{*}{ Site } & \multicolumn{9}{|c|}{ Dry season } & \multicolumn{4}{|c|}{ Rainy season } \\
\cline { 2 - 7 } & $\mathbf{M n}$ & $\mathbf{N i}$ & $\mathbf{C r}$ & $\mathbf{C d}$ & $\mathbf{P b}$ & $\mathbf{C u}$ & $\mathbf{Z n}$ & $\mathbf{M n}$ & $\mathbf{N i}$ & $\mathbf{C r}$ & $\mathbf{C d}$ & $\mathbf{P b}$ & $\mathbf{C u}$ & $\mathbf{Z n}$ \\
\hline Chirimba stream (A) & 0.27 & 0.70 & ND & 12.07 & 0.31 & 0.10 & 1.36 & 0.29 & ND & ND & 2.98 & 0.24 & 0.100 & 0.73 \\
\hline Chirimba stream (B) & 0.46 & 2.10 & ND & 19.13 & 0.11 & 0.09 & 0.40 & 0.06 & 0.19 & ND & ND & 0.08 & ND & 0.36 \\
\hline Mudi stream (A) & 0.29 & 0.25 & 0.0032 & 2.66 & 0.01 & 0.27 & 0.13 & 0.17 & 0.15 & ND & ND & 0.14 & 0.042 & 0.29 \\
\hline Mudi stream (B) & 0.28 & 2.46 & ND & 2.60 & 0.11 & 0.03 & 8.35 & 0.62 & 0.57 & ND & ND & ND & 0.211 & 0.72 \\
\hline Michiru stream & 0.19 & 0.03 & ND & ND & ND & 0.00 & 0.56 & 0.19 & 0.13 & ND & ND & ND & ND & 0.91 \\
\hline Naperi stream (A) & 0.12 & 0.41 & 0.0028 & 3.38 & 0.12 & 0.02 & 0.32 & 0.27 & 0.15 & ND & ND & ND & 0.003 & 0.73 \\
\hline Naperi stream (B) & 0.14 & 0.06 & ND & ND & ND & 0.03 & 0.47 & 0.22 & 0.31 & ND & ND & ND & 0.021 & 0.50 \\
\hline Blantyre WWTP & 0.08 & 0.21 & 0.0035 & 1.27 & 0.03 & 0.22 & 1.33 & 0.23 & 0.28 & ND & ND & ND & 0.070 & 0.28 \\
\hline Nasolo stream (A) & 0.24 & 3.36 & ND & ND & 1.44 & 0.22 & 0.30 & 0.28 & 0.72 & ND & ND & 0.41 & 0.068 & 0.57 \\
\hline Nasolo stream (B) & 0.14 & 0.67 & ND & ND & 4.44 & 0.43 & 0.16 & 0.19 & 0.35 & ND & ND & 0.30 & 0.027 & 0.25 \\
\hline Mzedi Stream & 0.43 & 0.11 & 0.0089 & 1.84 & 0.67 & 0.03 & 3.56 & 0.36 & ND & ND & ND & ND & ND & 0.48 \\
\hline Soche WWTP & 0.22 & 0.30 & 0.0073 & 7.83 & 0.29 & 0.01 & 0.28 & 0.31 & 1.08 & ND & ND & ND & 0.030 & 0.33 \\
\hline Limbe WWTP & 0.24 & 0.49 & ND & 3.08 & 0.33 & 0.48 & 0.65 & 0.66 & 0.35 & ND & ND & ND & 0.128 & 0.71 \\
\hline Limbe stream (A) & 0.22 & 0.03 & ND & ND & 0.03 & 0.24 & 0.58 & 0.74 & 1.34 & ND & ND & ND & 0.074 & 1.15 \\
\hline Limbe stream (B) & 0.07 & 32.38 & ND & 7.83 & 0.26 & 0.15 & 0.74 & 0.34 & 0.48 & ND & ND & ND & 0.094 & 0.52 \\
\hline
\end{tabular}

$\mathrm{ND}=$ not determined

Table 7. Bioconcentration factors (BCF) for rainy and dry seasons for A.icteria from the sampled stream-bank soils and soils around WWTPs in Blantyre City, Malawi. 

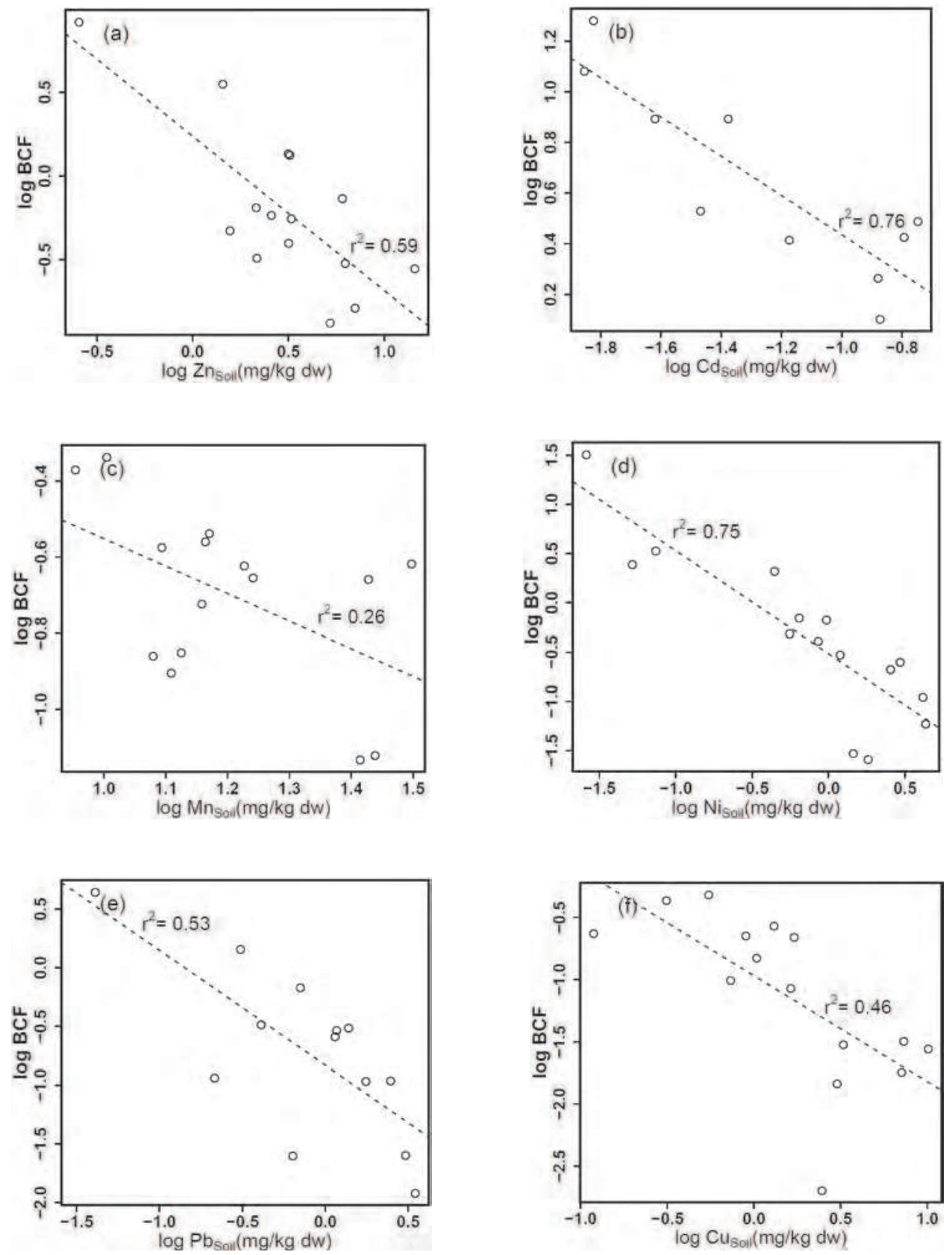

Fig. 3. Plots of $\log B C F$ against metal concentration in the soil using dry season data. 


\begin{tabular}{|c|c|c|c|c|c|c|c|c|c|c|c|}
\hline \multicolumn{2}{|c|}{ References } & \multirow[t]{2}{*}{ Species } & \multirow{2}{*}{$\begin{array}{c}\text { Equation } \\
\# \\
\end{array}$} & \multicolumn{2}{|c|}{ Cd } & \multicolumn{2}{|c|}{$\mathbf{P b}$} & \multicolumn{2}{|c|}{$\mathrm{Cu}$} & \multicolumn{2}{|c|}{ Zn } \\
\hline & & & & $a$ & $b$ & $a$ & $b$ & $a$ & $b$ & $a$ & $b$ \\
\hline $\begin{array}{l}\text { Heikens et } \\
\text { al. (2001) }\end{array}$ & $\begin{array}{l}\text { Bibliographic } \\
\text { study }\end{array}$ & $\begin{array}{l}\text { Lumbricidae } \\
\text { (mixed) }\end{array}$ & 1 & 0.39 & 1.1 & 0.62 & -0.3 & 0.17 & 1.8 & 0.17 & 1.8 \\
\hline $\begin{array}{l}\text { Ma et al. } \\
\text { (2004) }\end{array}$ & Field data & $\begin{array}{l}\text { Lumbricidae } \\
\text { (mixed) }\end{array}$ & 2 & 0.556 & 1.39 & 0.556 & 0.626 & 0.327 & 0.776 & 0.212 & 2.49 \\
\hline $\begin{array}{l}\text { Neuhauser } \\
\text { eta al. } \\
\text { (1995) }\end{array}$ & $\begin{array}{l}\text { Bibliographic } \\
\text { studies }\end{array}$ & $\begin{array}{l}\text { Lumbricidae } \\
\text { (all species } \\
\text { mixed) }\end{array}$ & 3 & 0.66 & 1.21 & 0.74 & 0.05 & 0.27 & 2.09 & 0.27 & 2.09 \\
\hline $\begin{array}{l}\text { Wright and } \\
\text { Stringer }\end{array}$ & $\begin{array}{l}\text { Soil quantity: } \\
\text { field study }\end{array}$ & $\begin{array}{l}\text { Aporrectodea } \\
\text { caliginosa }\end{array}$ & 4 & 0.32 & 0.33 & 0.9 & -0.8 & 0.01 & 0.23 & 0.01 & 0.23 \\
\hline (1980) & & $\begin{array}{l}\text { Aporrectodea } \\
\text { longa }\end{array}$ & 5 & 0.3 & -0.3 & 0.5 & -0.1 & 0.1 & 2.5 & 0.1 & 2.5 \\
\hline & & $\begin{array}{l}\text { Aporrectodea } \\
\text { rosea }\end{array}$ & 6 & 0.5 & 0.7 & 0.5 & -0.1 & 0.5 & 1.1 & 0.5 & 1.1 \\
\hline
\end{tabular}

Table 8. Regression equations, $\log M_{e w}=a \log M_{s}+b$ for Lumbricidae, Aporrectodea caliginosa, Aporrectodea longa, Aporrectodea rosea and $\mathrm{Cd}, \mathrm{Cu}, \mathrm{Pb}$ and $\mathrm{Zn}$ from literature
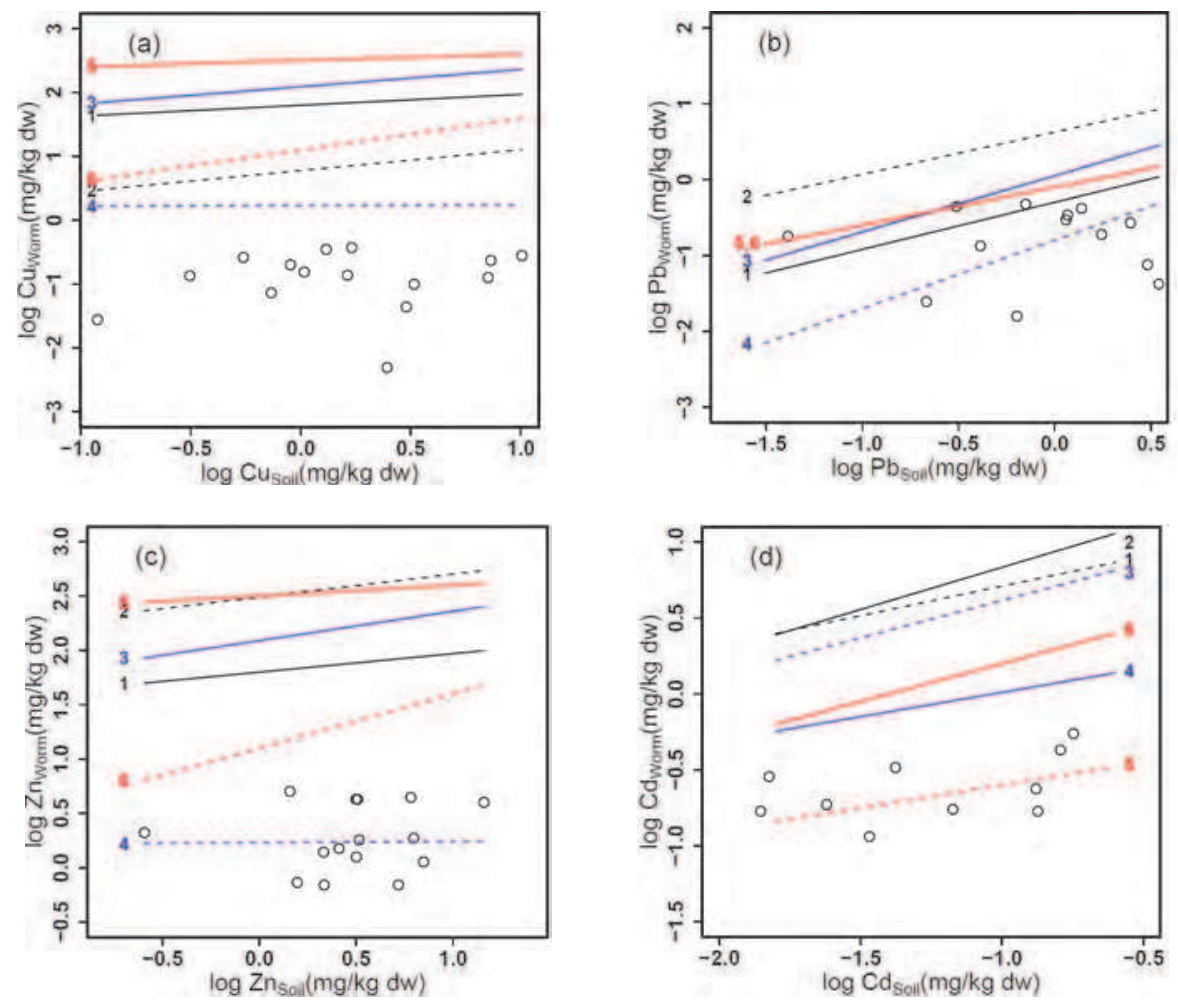

Fig. 4. Relationships between the internal $\mathrm{Cd}, \mathrm{Cu}, \mathrm{Pb}, \mathrm{Zn}$ in earthworms and the total soil concentration, in comparison with regressions from the literature. The number on the lines corresponds to the number of regression model in Table 8, calculated using the soil data from this study. The dots are data from this study (A.icteria) for dry season. 

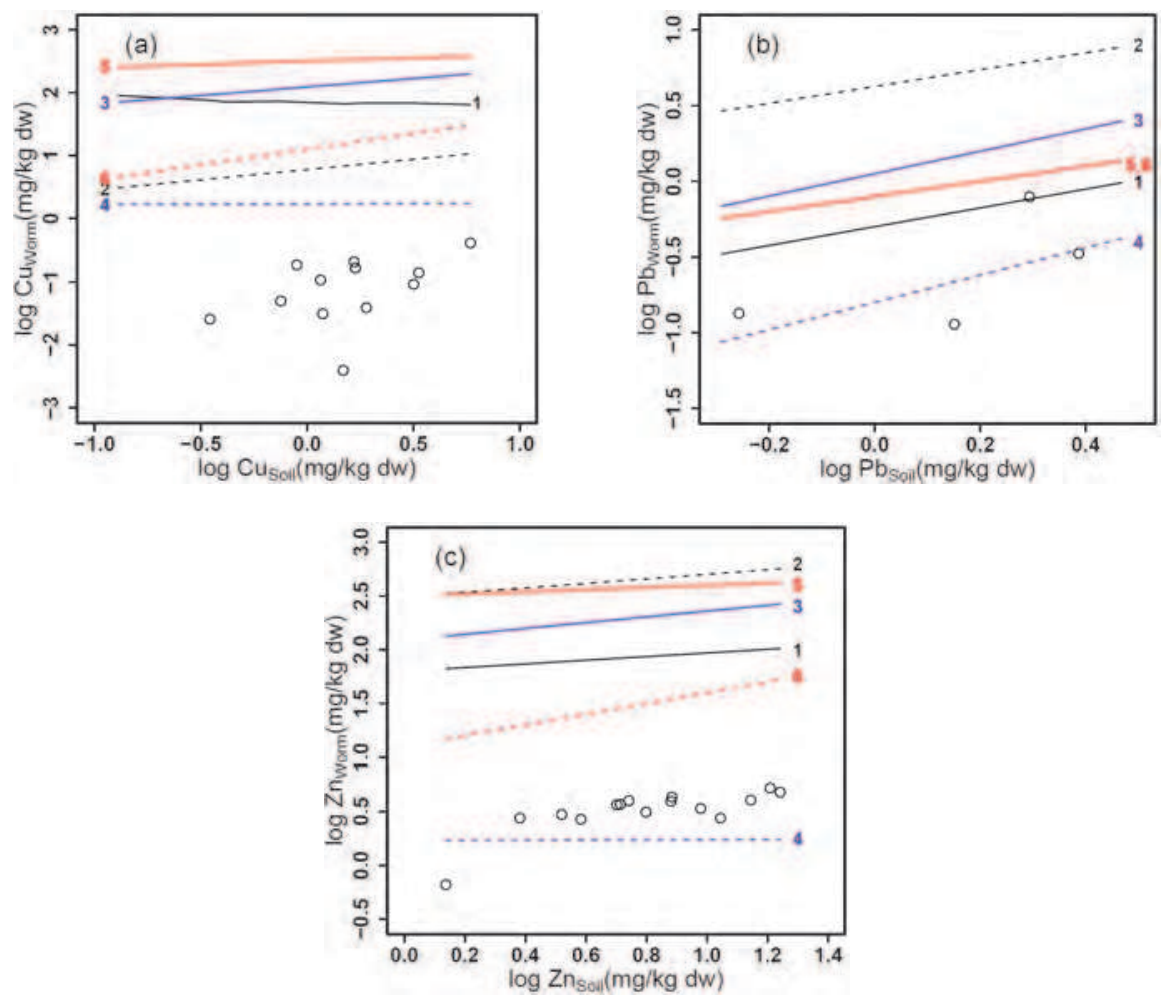

Fig. 5. Relationships between the internal $\mathrm{Cd}, \mathrm{Cu}, \mathrm{Pb}, \mathrm{Zn}$ in earthworms and the total soil concentration, in comparison with regressions from the literature. The number on the lines corresponds to the number of regression model in Table 8 , calculated using the soil data from this study. The dots are data from this study (A.icteria) for wet season.

Kamitani and Kaneko, 2007; Hsu et al., 2006; Dai et al, 2004; Ireland, 1983; Ma, 1982). The solubility of heavy metals in soil (pore) water is important for bioaccumulation by earthworms as the main pathways for chemical absorption are the skin (for soluble elements), gut transit and digestion (Weltje, 1998). The BCF order also reflects the affinity order for the specific adsorption of metal cations in soil: $\mathrm{Pb}>\mathrm{Cu}>\mathrm{Zn}>\mathrm{Cd}$. Cadmium tends to be more mobile in soils and therefore more available to earthworms than other heavy metals (Ma, 2004). Fig. 3 shows decreasing BCF with soil concentration of the metals indicating that bioconcentration depends on the metal concentrations in the soil and is greater at low soil concentrations. This implies that $A$. icteria exhibits metal regulation at high exposure rates (Neuhauser et al., 1995).

There is a significant consensus in the literature that bioaccumulation of heavy metals by earthworms is dependent on earthworm species and type of metal (see e.g. van Vliet et al., 2005, 2006; Vijver, 2007; Kamitani and Kaneko, 2007; Ernst et al., 2008).

Hence, the accumulation patterns of $\mathrm{Cd}, \mathrm{Cu}, \mathrm{Zn}$ and $\mathrm{Pb}$ in A. icteria (this study) were compared to those of other lumbricid earthworms, using the regression models from literature (Heikens et al., 2001; Neuhauser et al., 1995; Ma, 2004; Wright and Stringer, 1980) 
(see Table 8). Data for A. icteria is not readily available in the literature for comparison with our study. Figs 4 and 5 show that A. icteria (present study) accumulated relatively less $\mathrm{Cu}$ than the other species at the same soil concentration. However, similar accumulation levels were observed for $\mathrm{Pb}$ and $\mathrm{Zn}$ with $\mathrm{A}$. caliginosa and for $\mathrm{Cd}$ with $\mathrm{A}$. longa (Figs 4 and 5), even at our very low exposure levels. For all species, there is a metal dependent increase in body concentration with increasing soil concentration, following the order: $\mathrm{Pb}>\mathrm{Cd}>\mathrm{Cu}=\mathrm{Zn}$ (Figs. 4 and 5). $\mathrm{Cu}$ and $\mathrm{Zn}$ are essential metals and are physiologically regulated by earthworms, resulting in a relatively constant body concentration with respect to soil metal concentrations (Panda et al., 1999; Heikens, et al., 2001; Morgan and Morgan, 1988; Lukkari, 2004). In contrast, $\mathrm{Cd}$ and $\mathrm{Pb}$ are non-essential metals and are not regulated resulting in metal increase with increasing soil concentrations (Spurgeon and Hopkin, 1999).

The plots in Figs. 4 and 5 also show that the regression models generated for all species of lumbricid earthworms would overestimate the amount of heavy metals in A. icteria living in the stream bank soils and soils around the WWTPs in Blantyre City. This result supports the general consensus that the degrees of heavy metal accumulation in earthworms show different, metal- and species-specific patterns. The observed differences in accumulation patterns are usually attributed to differences in metal kinetics of the earthworms, exposure route and food preference. In addition, it seems that the accuracy of the regression models is lost when they are generalised at family level but may be possible to relate accumulation patterns within the same genera. However, it should be noted that the comparison should be made with caution because metal availability is dependent on several environmental factors such as soil $\mathrm{pH}$, cation exchange capacity, $\mathrm{OM}$ and $\mathrm{Ca}^{2+}$ (Christensen, 1989, Ma, 1982; Corp and Morgan, 1991; Peijnenburg et al., 1999a, 1999b). These factors may differ between studied field soils.

\section{Conclusions}

The study obtained concentrations of manganese, cadmium and lead in periphyton ( $S$. aequinoctialis) in higher levels than in the corresponding water, implying that $S$. aequinoctialis accumulates these heavy metals. The results indicate the potential of periphyton as a biological indicator of heavy metal pollution. Heavy metals concentrations therefore measured in macroalgae species can give a picture of the quality of our surrounding environment. In addition, the levels of most of the heavy metals were higher than drinking water standards. It was also found that the general trend was that of high heavy metal values for water samples in the dry season than in the rainy season. The relatively low heavy metal levels in the rainy season were attributed to dilution. The study also showed that $A$. icteria can accumulate cadmium, but not lead and manganese. This work supports the published results that metal- and species-specific accumulation patterns of non-essential heavy metals in earthworms occur. In addition, the work extends the database to even very low exposure levels and therefore generates more information for A. icteria. Metal accumulation shows seasonal variations with significant correlations and multiple regression models between soil and internal metal content being more apparent in the rainy season. Similar accumulation levels observed between $A$. icteria and $A$. caliginosa for $\mathrm{Pb}$ and $\mathrm{Zn}$ and $A$. longa for $\mathrm{Cd}$ point to a possibility to relate accumulation patterns within the same genera, albeit metal specific. Further, it seems that the accuracy of regression models is lost when they are generalised at family level, making generalisations at that level difficult. 


\section{Acknowledgements}

The authors would like to thank University of Malawi, The Polytechnic for funding this study. They are greatly indebted to Blantyre City Assembly for allowing them to collect samples in places that they use for their routine monitoring work. Thanks should also go to technical staff of Chancellor College Faculty of Science, all laboratory staff at Geological Surveys Department and National Herbarium and Botanical Gardens for their technical support.

\section{References}

Ackcali, I., Kucuksezgin, F. (2011). A biomonitoring study: Heavy metals in macroalgae from eastern Aegean coastal areas. Marine Pollution Bulletin, Vol 62, pp: 637-645, ISSN 0025326X

Alloway, B.J., \& Ayres D.C. (1997). Chemical Principles of Environmental Pollution (2nd Edition), Blackie Academic \& Professional, ISBN 0751403806, London

American Public Health Association, (APHA). (2005). Standard Methods for the Examination of Water and Wastewater (21 ${ }^{\text {st }}$ Edition), APHA, ISBN 0875532233, Washington DC

Anderson, J.M., \& Ingram, J.S.I. (1993). Tropical Soil Biology: A Handbook of Methods (2nd Edition), CAB International, ISBN 0851988210, UK

Association of Official Analytical Chemists, (AOAC). (1990). Official Methods of Analyses (15 Edition), AOAC, ISBN 8787200848, New York, USA

Bamgbose, O., Odukoya, O., \& Arowolo, T.O.A. (2000). Earthworms as bio-indicators of heavy metal pollution in dumpsites of Abeokuta city, Nigeria. Rev. Biol. Trop., Vol. 48, No. 1, (March 2000), pp. 229 - 234, ISSN 0034-7744

Bohn, H.L., McNeal, B.L. \& O'Connor, G.A. (1985). Soil Chemistry (2nd Edition). John Wiley and Sons, ISBN 0471822175, New York

Burns, A., \& Ryder, D.S. (2001). Potential for biofilms as biological indicators in Australian riverine systems. Ecological Management E Restoration, Vol. 2, No. 1, (April 2001), pp. 53-64, ISSN 14428903

Christensen, T.H. (1989). Cadmium soil sorption at low concentrations. Correlation woth soil parameters. Water Air Soil Pollution, Vol 44, pp: 71-82, 00496979

Chukwuma, C. (1998). Environmental issues and our chemical world - The need for a multidimensional approach in environmental safety, health and management. Environmental Management and Health, Vol. 9, No. 3, pp. (136- 143), ISSN 09566163

Corp, N., Morgan, A.J. (1991). Accumulation of heavy metals from polluted soils by the earthworm, Lumbricus rubellus: can laboratory exposure of 'control' worms reduce biomonitoring problems? Environmental Pollution, Vol 74, pp: 39-52, ISSN 02697491

Cuffney, T.F.,Meador, M.R., Porter, S.D. \& Curtz, M.E. (2000). Responses of physical, chemical and biological indicators of water quality to a gradient of agricultural land use in the Yakima River Basin, Washington. Environmental Monitoring and Assessment, Vol. 64, No.1, (September 2000), pp. 259-270, ISSN 01676369

Dai, J., Becquer, T., Rouiller, J.H., Reversata, G., Bernhard-Reversata, F., Nahmania, J., Lavelle, P. (2004). Heavy metal accumulation by two earthworm species and its relationship to total and DTPA-extractable metals in soils. Soil Biology and Biochemistry, Vol 36, pp: 91-98, ISSN 00380717 
DARES (Diatoms for Assessing River Ecological Status). (2004). Sampling protocol version 1.0., In: Diatoms for Assessing River Ecological Status, Accessed on 11/07/2010, Available from <http://craticula.ncl.ac.uk/DARES/methods/DARESProtocol DiatomSampling.pdf $>$

Davies, T.A., Volesky, B., Mucci, A. (2003). A review of the biochemistry of heavy metal biosorption by brown algae. Water Research. Vol 37, pp: 4311-4330, ISSN 00431354

EMAN (Ecological Monitoring and Assessment Network). (2004). Worm species richness, In: Environment Canada, Accesed on 11/07/2010, Available from <http://www.emanrese.ca/eman/ecotools/protocols/terrestrial/earthworm/intr o.html>

Ernst, G., Zimmermann, S., Christie, P. \& Frey, B. (2008). Mercury, cadmium and lead concentrations in different ecophysiological groups of earthworms in forest soils. Environmental Pollution, Vol. 156, No. 3, (April 2008), pp. 1304 - 13, ISSN 02697491

Favero, N., Cattalini, F., Bertaggia, D. \& Albergoni, V. (1996). Metal accumulation in a biological indicator (Ulva rigida) from the lagoon of Venice (Italy). Archives of Environmental Contamination and Toxicology, Vol. 31, No. 1, (January 1996), pp.918, ISSN 14320703

Filho, A.G.M., Andrade, L.R., Karez, C.S., Farina, M., Pfeiffer, W.C. (1999). Brown algae species as bimonitors of $\mathrm{Zn}$ and $\mathrm{Cd}$ at Sepetiba Bay, Rio de Janeiro, Brazil. Marine Environmental Research. Vol 48, pp:213-224, ISSN 01411136

Gekeler, W., Grill, E., Winnacker, E.L. \& Zenk, M.H. (1988). Algae sequester heavy metals via synthesis of phytochelatin complexes. Archives of Microbiology, Vol. 150, No. 2, pp.197-202, ISSN 1432072X

Georgescu, B. \& Weber, C. (2007). The role of earthworms as biological indicators of soil contamination. Animal Science and Biotechnologies, Vol. 64, No. 1-2, ISSN 18435254

Garnharm, G.W., Codd, G.A., Gadd, G.M. (1992). Kinetics of uptake intracellular locations of cobalt, manganese and zinc in the estuarine green alga Chlorella salina. Applied Microbiology and Biotechnology, Vol 37, pp: 270-276, ISSN 14320614

Heikens, A., Peijnenburg, W.J.G.M., Hendriks, A.J. (2001). Bioaccumulation of heavy metals in terrestrial invertebrates. Environmental Pollution, Vol113, pp: 385-393, ISSN 02697491

Hill, B.H., Herlihy, A.T., Kaufmann, P.R., Stevenson, R.J., McCormick F.H. and Johnson C.B., (2000) Use of periphyton assemblage data as an index of biotic integrity. Journal of the North American Benthological Society, Vol. 19, No. 1, (March 2000), pp. 50-67, ISSN 08873593

Hoffman, S. (1996). My trip to Upper Klamath Lake during the 1996 full eclipsed harvest moon, Accessed on 21/06/2010, Available from <http://www.algae-world.com/algae/12.htmL>

Holan, Z.R., Volesky, B. \& Prasetyo, I. (1993). Biosorption of cadmium by biomass of marine algae. Biotechnology and Bioengineering, (April 1993), Vol. 41, No. 8, pp. 819-825, ISSN 00063592

Hui, C. A.(2002). Lead distribution throughout soil, flora, and an invertebrate at a wetland skeet range. Journal of Toxicology and Environmnetal Health, Vol 65, pp: 1093-1107, ISSN 15287394 
Hsu, M.J., Selvaraj, K., Agoramoorthy, G. (2006). Taiwan's industrial heavy metal pollution threatens terrestrial biota. Environmental Pollution, Vol 143, pp: 327-334, ISSN 02697491

Ireland, M.P. (1983). Heavy metal uptake and tissue distribution, In: Earthworms Ecology from Darwin to Vermiculture, E.J. Satchell, pp. 247 - 265, Chapman and Hall, ISBN 9788179102299, London

Ireland, M.P., Richards, K. S. (1977). The occurrence and localisation of heavy metals and glycogen in earthworms Lumbricus rubellus and Dendrobaena rubida from a heavy metal site. Histochemistry, Vol.51, pp: 153-166, ISSN 11214201

ISO (International Standards Organisation), 1994. Water quality- Determination of $\mathrm{pH}$. ISO 10523-1, ISO, Geneva

Jin-fen, P., Rong-gen, L. \& Li, M. (2000). A review of heavy metal adsorption by marine algae. Chinese Journal of Oceanology and Limnology, Vol. 18, No. 3, pp.260-264, ISSN 02544059

Kadewa, W. W., Henry, E. M., Masamba, W. R. M. \& Kaunda, C. C. (2001). Impact of sewage sludge application to horticulture: A case of the city of Blantyre, Proceedings of the first Chancellor College research dissemination conference, Zomba, Malawi, (n.d)

Kamitani, T. \& Kaneko, N. (2007). Species-specific heavy metal accumulation patterns of earthworms on afloodplain in Japan. Ecotoxicology and Environmental Safety, Vol. 66, No. 1, (January 2007), pp. 82-91, ISSN 01476513

Khan, I. S. A. N. (1990). Assessment of water pollution using diatom community structure and species distribution - A case study in a tropical river basin. Internationale Revue der gesamten Hydrobiologie und Hydrographie, Vol. 75, pp.317-338, ISSN 15222632

Khosmanesh, A., Lawson, F. \& Prince, I.G. (1996). Cadmium uptake by unicellular green microalgae. The Chemical Engineering Journal and the Biochemical Engineering Journal, Vol. 62, No.1, (April 1996), pp. 81-88, ISSN 09230467

Kuyeli, S.M. (2007). Assessment of industrial effluents and their impact on water quality in streams of Blantyre City, Malawi. Unpublished MSc Thesis. University of Malawi.

Lakudzala D.D, Tembo K.C and Manda I.K (1999). An investigation of chemical pollutants in Lower Shire River, Malawi. Malawi Journal of Science and Technology, Vol. 5, pp. 87-94, ISSN 1019 - 7079

Langdon, C.J., Pearce, T.G., Meharg, A.A., Semple, K.T. (2001) Resistance to copper toxicity in populations of the earthworms Lumbricus rubellus and Dendrodrilus rubidus from contaminated mine wastes. Environmental Toxicology and Chemistry, Vol 20, pp: 2336-2341, ISSN 15528618

Lukkari ,T., Taavitsainen, M, Väisänen, A. \& Haimi, J. (2004). Effects of heavy metals on earthworms along contamination gradients in organic rich soils. Ecotoxicology and Environmental Safety, Vol. 59, No. 3, (November 2004), pp. 340-348, ISSN 01476513

Ma, W-C. (1982). The influence of soil properties and worm-related factors on the concentration of heavy metals in earthworms. Pedobiology, Vol 24, pp:109-119, ISSN 0046225X

Ma, W-C. (2004). Estimating heavy metal accumulation in oligochaete earthworms: a metaanalysis of field data. Bulletin of Environmental Contamination and Toxicology, Vol 72, pp: 663-670, ISSN 14320800 
Manly, R. (1996). Biological indicators, In: Environmental Analytical Chemistry, F.W Fifield \& P.J Haines, pp. (249 -274), Blackie Academic \& Professional, ISBN 0632053836, London

MBS (Malawi Bureau of Standards). (2005). Drinking Water Specification, MS 214:2005, First Revision

McCornick, P.V. \& Cairns, J. (1994). Algae as indicators of environmental change. Journal of Applied Phycology, Vol. 6, No. 5-6, pp.509-526, ISSN 09218971

Morgan, J.E. \& Morgan, A.J. (1988). Earthworms as biological monitors of cadmium, copper, leadand zinc inmetalliferous soils. Environmental Pollution, Vol. 54, No. 2, (March 1988),pp. 123-138, ISSN 02697491

Neuhauser E.F., Cukic Z.V., Malecki M.R., Loehr R.C. and Durkin P.R., (1995). Bioconcentration and biokinetics of heavy metals in the earthworm. Environmental Pollution, Vol. 89, No. 3, pp. 293-301, ISSN 02697491

NSW (New South Wales). (2002). Blue green algal bloom management, In: New South Wales Regional Algal Coordinating Committee, Accesed on 21/06/2011,Availablefrom: <http:/ / www.murraybluegreenalgae.com/whattodonext.htm\#STEP\%201>

OIS. (1998). Swiss Ordinance relating to Impacts on the Soil: $1^{\text {st }}$ July 1998. SR 814.12 Switzerland, 1998.

Panda, R., Pati, S.S., Sahu, S.K. (1999). Accumulation of zinc and its effects on the growth, reproduction and life cycle of Drawida willsi (Oligochaeta), a dominant earthworm in Indian crop fields. Biology and Fertility of Soils, Vol 29, pp: 419-423, ISSN 01782762

Peijnenburg, W.J.G.M., Posthuma, L., Zweers, P.G.P.C., Baerselman, R., de Groot, A.C., Van Veen, R.P.C., Jager, D.T. (1999a). Relating environmental availability to environmetal bioavailability: soil type dependent metal accumulation in the oligochaete Eisenia andrei. Ecotoxicology and Environmental Safety, Vol 44, pp: 294310, ISSN 01476513

Peijnenburg, W.J.G.M., Posthuma, L., Zweers, P.G.P.C., Baerselman, R., de Groot, A.C., Van Veen, R.P.C., Jager, D.T. (1999b). Prediction of metal bioavailability in Dutch field soils for the oligochaete Enchytraeus crypticus. Ecotoxicology and Environmental Safety, Vol 43, pp: 170-186, ISSN 01476513

Rajfur, M., Klos, A, Waclawek, M. (2010). Sorption properties of algae Sprogura sp. And their use for determination of heavy metal ions concentrations in surface water. Biolectrochemsitry, Vol 80, pp:81-86, ISSN 15675394

Ramelow, G.J., Maples, R.S., Thompson, R.L., Mueller, C.S., Webre, C. \& Beck, J.N. (1987). Periphyton as monitors for heavy metal pollution in the Calcasieu River estuary. Environmental Pollution, Vol. 43, No. 4, pp. 247-261, ISSN 02697491

Spurgeon, D.J., Hopkin, S.P. (1999). Tolerance of zinc in populations of the earthworm Lumbricus rubellus from uncontaminated and metal-contaminated ecosystems. Archives of Environmental Contamination and Toxicology, Vol 37, pp: 332-337, ISSN 14320703

Spurgeon, D.J., Svendsen, C., Rimmer, V.R., Hopkin, S.P., Weeks, J.M. (2000). Relative sensitivity of life-cycle and biomarker responses in four earthworm species exposed to zinc. Environmental Toxicology and Chemistry, Vol 19, pp: 1800-1808, ISSN 15528618 
Sajidu, S.M.I., Masamba, W.R.L., Henry, E.M.T. \& Kuyeli S.M. (2007).. Water quality assessment in streams and wastewater treatment plants of Blantyre, Malawi. Physics and Chemistry of the Earth; Vol 32, No. 15, pp. 1391-1398, ISSN 14747065

United States Environmental Protection Agency (US-EPA). (2010). Target analyte metals (Heavy metals) and cyanide, Accessed on 11/01/10, Available from; http://www.epa.gov/reg3hwmd/bf-lr/regional/analytical/metals.htm Van Vliet, P.C.J., Didden, W.A.M., Van der Zee, S.E.A.T.M., Peijnenburg, W.J.G.M. (2006). Accumulation of heavy metals by enchytraeids and earthworms in a floodplain. European Journal of Soil Biology, Vol 42, pp: S117-S126, ISSN 11645563

Van Vliet, P.C.J., van der Zee, S.E.A.T.M., Ma, W-C. (2005). Heavy metal concentrations in soil and earthworms in a floodplain grassland. Environmental Pollution, Vol 138, pp: 505-516, ISSN 02697491

Vijver, M.G., Vink, J.P.M., Miermans, C.J.H., van Gestel, C.A.M. (2007). Metal accumulation in earthworms inhabiting floodplain soils. Environmental Pollution, Vol 148, pp: 132140, ISSN 02697491

Vyas, N.B., Spann, J.W., Heinz, G.H., Beyer, W.N., Jaquette, J.A., Mengelkoch, J.M. (2000). Lead poisoning of passerines at a trap and skeet range. Environmental Pollution, Vol 107, pp: 159-166, ISSN 02697491

Walkley, A.J., Black, I.A. (1934). An examination of the Degtjareff method for determining soil organic matter and a proposed modification of the chromic acid titration method. Soil Science, Vol 37, pp: 29-38, ISSN 15389243

Weltje, L. (1998). Mixture toxicity and tissue interactions of $\mathrm{Cd}, \mathrm{Cu}, \mathrm{Pb}$ and $\mathrm{Zn}$ in earthworms (Oligochaeta) in laboratory and field soils: a critical evaluation of data. Chemosphere, Vol 36, pp: 2643-2660, ISSN 00456535

WHO (World Health Organization), (2006). Guidelines for drinking water quality 3rd Edition, Accessed on 11/06/2010,Available from: <http://www.who.int/watersanitationhealth/dwq/gdwq3rev/en/ index html>

Wright, M.A. \& Stringer, A. (1980). Lead, zinc and cadmium content of earthworms from pasture in the vicinity of an industrial smelting complex. Environmental Pollution Series A, Ecological and Biological ,Vol. 23, No. 4, (December 1980), pp. 313-321, ISSN 01431471

Żbikowski, R., Szefer, P., Latala, A. (2007). Comparison of green algae Cladophora sp. And Enteromorpha sp. as potential biomonitors of chemical elements in the southern Baltic. Science of the Total Environment, Vol 387, pp: 320-332, ISSN 00489697 


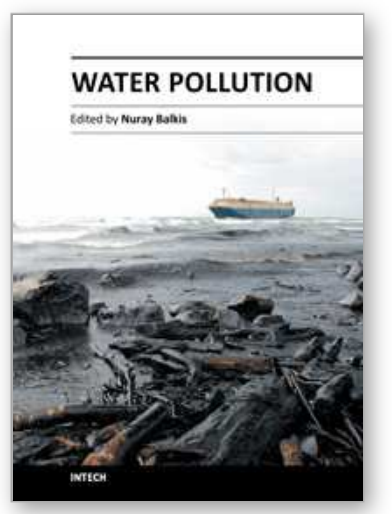

\author{
Water Pollution \\ Edited by Prof. Nuray Balkis
}

ISBN 978-953-307-962-2

Hard cover, 202 pages

Publisher InTech

Published online 24, February, 2012

Published in print edition February, 2012

Water pollution is a major global problem that requires ongoing evaluation and revision of water resource policy at all levels (from international down to individual aquifers and wells). It has been suggested that it is the leading worldwide cause of deaths and diseases, and that it accounts for the deaths of more than 14,000 people daily. In addition to the acute problems of water pollution in developing countries, industrialized countries continue to struggle with pollution problems as well. Water is typically referred to as polluted when it is impaired by anthropogenic contaminants and either does not support a human use, such as drinking water, and/or undergoes a marked shift in its ability to support its constituent biotic communities, such as fish. Natural phenomena such as volcanoes, algae blooms, storms, and earthquakes also cause major changes in water quality and the ecological status of water. Most water pollutants are eventually carried by rivers into the oceans.

\title{
How to reference
}

In order to correctly reference this scholarly work, feel free to copy and paste the following:

C. C. Kaonga and M. Monjerezi (2012). Periphyton and Earthworms as Biological Indicators of Metal Pollution in Streams of Blantyre City, Malawi, Water Pollution, Prof. Nuray Balkis (Ed.), ISBN: 978-953-307-962-2, InTech, Available from: http://www.intechopen.com/books/water-pollution/periphyton-and-earthworms-asbiological-indicators-of-heavy-metal-pollution-in-streams-of-blantyre-m

\section{INTECH}

open science | open minds

\section{InTech Europe}

University Campus STeP Ri

Slavka Krautzeka 83/A

51000 Rijeka, Croatia

Phone: +385 (51) 770447

Fax: +385 (51) 686166

www.intechopen.com

\section{InTech China}

Unit 405, Office Block, Hotel Equatorial Shanghai

No.65, Yan An Road (West), Shanghai, 200040, China

中国上海市延安西路65号上海国际贵都大饭店办公楼 405 单元

Phone: +86-21-62489820

Fax: $+86-21-62489821$ 
(C) 2012 The Author(s). Licensee IntechOpen. This is an open access article distributed under the terms of the Creative Commons Attribution 3.0 License, which permits unrestricted use, distribution, and reproduction in any medium, provided the original work is properly cited. 